\title{
Seasonal biology of Melanagromyza albocilia (Diptera: Agromyzidae) and seasonal patterns of field bindweed infestation, under field conditions in Slovakia
}

\author{
Peter Tóth, Massimo Cristofaro \& Ludovít Cagán̆
}

Tóth, P., Cristofaro, M. \& Cagáň, Ĺ. 2005: Seasonal biology of Melanagromyza albocilia (Diptera: Agromyzidae) and seasonal patterns of field bindweed infestation, under field conditions in Slovakia. - Entomol. Fennica 16: 254-262.

Melanagromyza albocilia Hendel, a stem borer of field bindweed (Convolvulus arvensis) was observed at three sites in Slovakia during 1999 and 2000. The insect overwintered as pupa. The first generation adults emerged in May and those of second during June-August. Percentage of infested field bindweed plants varied from $46.7 \%$ to $99.2 \%$ and number of infested stems from $4.1 \%$ to $37.2 \%$. Infested stems contained an average of $0.84 \pm 0.40$ to $1.34 \pm 0.50$ specimens (larvae, parasitized larvae, pupae). The population of M. albocilia was the highest in 1999 , with mean densities of $1.57 \pm 1.01$ to $3.21 \pm 2.13$ specimens/plant. All parasitoids emerged from larvae were identified as Bracon picticornis Wesmael.

P. Tóth, Slovak Agricultural University, Department of Plant Protection, A. Hlinku 2,94976 Nitra, Slovak Republic; E-mail: petery@nextra.sk

M. Cristofaro, ENEA C. R. Casaccia, BIOTEC, via Anguillarese 301, 00060 Rome, Italy; E-mail: massimo.cristofaro@casaccia.enea.it

L. Cagáň, Slovak Agricultural University, Department of Plant Protection, A. Hlinku 2, 94976 Nitra, Slovak Republic; E-mail: ludovit.cagan@uniag.sk

Received 21 January 2004, accepted 15 August 2005

\section{Introduction}

Field bindweed (Convolvulus arvensis Linnaeus) is considered one of the most important weeds in the world. Many scientists have surveyed phytophagous insects associated with Convolvulus spp., usually to find and evaluate potential biocontrol agents. Mohyuddin (1969) listed 125 insects and mites known to attack Convolvulus spp. and Calystegia spp. found by him in Canada and by others throughout the world. In Pakistan, Baloch (1974) found 35 species of insects and 2 species of mites in association with Convolvulus spp. The insect fauna noted on the field bindweed in Egypt consisted of 13 species (Awadallah et al.
1976). In Mediterranean Europe, 139 species of phytophagous arthropods were collected from C. arvensis and its close relatives (Rosenthal \& Buckingham 1982). For more details, see Tóth \& Cagáň (2005).

During 1996, field surveys of phytophagous insects associated with Convolvulus spp. started at various localities of Slovakia. During the study, high numbers of data have been collected, and partly already published (Tóth et al. 1997, 1998, 2001, 2003, Tóth 2000, Défago et al. 2001, Tóth \& Cagán̆ 2005). Melanagromyza albocilia Hendel, 1931 (Diptera: Agromyzidae), a native European stem borer of C. arvensis, was considered as a very promising candidate for the biolog- 
Table 1. Details of localities weekly checked in southwest of Slovakia for the occurrence of $M$. albocilia (19982000) . Coord. = coordinates; Alt. = altitude in metres; Temp. = average temperature in ${ }^{\circ} \mathrm{C}$; Rad. = global radiation; Crop $=$ covering crop species.

\begin{tabular}{|c|c|c|c|c|c|c|}
\hline Locality & Alt. ${ }^{a}$ & Coord. ${ }^{a}$ & Relief & Temp. & Rad. $^{\mathrm{b}}$ & Crop \\
\hline Čajkov & 206 & $\begin{array}{l}48^{\circ} 17^{\prime} 51^{\prime \prime N} \\
18^{\circ} 35^{\prime} 36^{\prime \prime E}\end{array}$ & Plain & 9.0 & $105-110$ & Sunflower \\
\hline $\begin{array}{l}\text { Malá n / } \\
\text { Hronom }\end{array}$ & 103 & $\begin{array}{l}47^{\circ} 50^{\prime} 45^{\prime \prime} \mathrm{N} \\
18^{\circ} 41^{\prime} 24^{\prime \prime} \mathrm{E}\end{array}$ & $\begin{array}{l}\text { Hilly } \\
\text { country }\end{array}$ & 10.2 & $115<$ & Sunflower \\
\hline Tehla & 194 & $\begin{array}{l}48^{\circ} 12^{\prime} 16^{\prime \prime N} \\
18^{\circ} 21^{\prime} 53^{\prime \prime} \mathrm{E}\end{array}$ & $\begin{array}{l}\text { Hilly } \\
\text { country }\end{array}$ & 9.7 & $110-115$ & Sunflower \\
\hline
\end{tabular}

a Magellan GPS 315

b According to Zatko (2002); Global radiation is expressed in $\mathrm{kcal} / \mathrm{cm}^{2}$

ical control of bindweed (Tóth et al. 1998, 2000).

This was the reason for the intensive study of this species.

Very little information is available about $M$. albocilia. It is a greenish-black species with wing length from $2.1 \mathrm{~mm}$ in male to $2.5 \mathrm{~mm}$ in female (Hendel, 1938, Spencer, 1966). It is known from Austria and Hungary (Hendel 1938, Soós \& Papp 1984), Egypt (Spencer 1973, Awadallah et al. 1976), Israel (Spencer 1973, 1974), England, Denmark and Sweden (Spencer 1976), Italy (Rosenthal \& Buckingham 1982), Czech Republic (Vála \& Černý 1997), Slovakia (Tóth et al. 1998) and Serbia (Spasic \& Smiljanic 1998). Females of $M$. albocilia insert their eggs under the epidermis of field bindweed leaves. Hatched larvae feed on the leaf tissue and make linear serpentine mines extending to the midribs, where each larva bores downwards towards the base of the stem or even into the root. At this site, pupation takes place after the larva gnaws an oval exit hole through which the emerged adult can find its way out (Awadallah et al. 1976). M. albocilia has been recorded solely from field bindweed in nature, though Rosenthal and Buckingham (1982) listed also Convolvulus althaeoides L. as an alternative host.

A related species $M$. convolvuli Spencer, 1971 was found in $C$. arvensis stems in Pakistan (Spencer 1971). Females of M. convolvuli puncture $C$. arvensis leaves with their ovipositors and feed on the ensuing exudates (Baloch 1977). Larval feeding of $M$. convolvuli in the stems or lateral branches considerably weakens the plant and in non-irrigated areas of limited rainfall the combined effect of the drought and larval attack causes the infested branches to dry up (Spencer 1973).

Because of the cryptic behavior of $M$. albocilia, little or no information exists on its occurrence during the growing season and infestation of the host plant. The objectives of this study were to determine the following: (1) occurrence and abundance of $M$. albocilia in cultivated areas in Slovakia; (2) the over-wintering survival and emergence pattern of $M$. albocilia; (3) the seasonal biology of M. albocilia; and (4) the infestation rate of field bindweed in the southwest of Slovakia.

\section{Material and methods}

To determine the seasonal occurrence of $M$. albocilia and field bindweed infestation by the agromyzid fly under field conditions in Slovakia, phenologically mature plants from 91 localities were investigated during the growing seasons of 1999 and 2000. Three localities in the southwest of Slovakia (Table 1) were checked weekly, from the end of May until the beginning of October. Crops, where the samples were taken, were grown according to local farmers' practices.

Each week thirty plants per site were randomly selected for dissection. For each selected plant, the number of healthy, dried and infested stems was recorded. The stems were periodically dissected for developmental specimens (larvae, pupae and parasitized larvae). The presence of the larvae and pupae could be detected only when the plants were dissected. The stems and roots were first cut across (a few cm above the root). The in- 


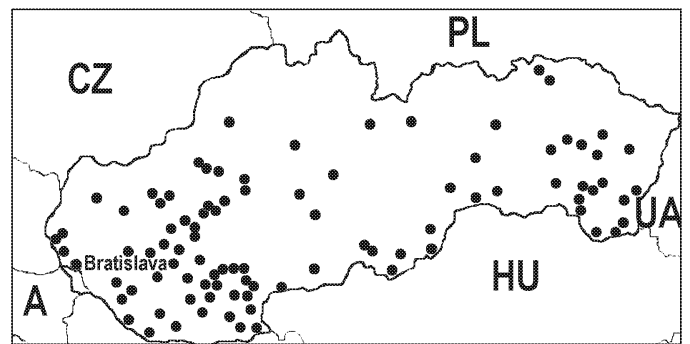

Fig. 1. Occurrence of Melanagromyza albocilia Hendel in Slovakia (black dots indicate localities where the species was recorded).

fested stems were clearly visible due to the brown interior or the hole, such stems were separated. The rest of stems were cut across again about ten centimeters higher.

The procedure was repeated along the whole length of the stem to note infestation. The stems with no infestation were considered as health; as well plants without infested stems were marked as health plants. Based on these results, percentage of infested plants and stems was calculated. Separated (infested) stems were split lengthwise. By following the feeding track of the larvae either down or up the stems, the larvae or pupae normally could be found. Pupae obtained in this way were transferred to rearing containers. Within the stems and roots of each plant, the position and number of larvae, pupae and parasitized larvae was recorded. Pupae and parasitized larvae were transferred in plastic tubes to the laboratory.

The material was kept in plastic tubes with a perforated top for aeration in an outdoor insectary to assess the period of adult emergence. Emerged larval parasitoids were collected, counted and submitted for identification. Voucher specimens of parasitoids have been retained in the collection of the first author. Besides the regular observations during 1999 and 2000, pupae and parasitized larvae of $M$. albocilia were collected at the three localities also during the fall season of 1998 to determine its over-wintering behavior.

In addition, 88 further localities were sampled throughout Slovakia, in different geographic and climatic regions, during the fall seasons of $1998-$ 2000 (Fig. 1) to record the presence of the agromyzid fly in the stems. Starting with a sample of 10 plants per site, the number reached a maximum of 30 plants per site if fly larvae and/or pupae were not found within the first 10 plants.

\section{Results}

\subsection{Distribution}

The distribution of $M$. albocilia in Slovakia is shown in Fig. 1. The fly was found at 91 localities, confirming that it is a common insect in Slovakia and it is closely related to the distribution of its host $C$. arvensis. The species occurred even at colder localities with an altitude more than $400 \mathrm{~m}$ a.s.l. and the infestation achieved similar levels to those at lower situated and warmer localities. But larvae were not parasitized at colder localities at higher altitudes $(285-435 \mathrm{~m}$ a.s.1.). The highest altitude where larval parasites were observed was $240 \mathrm{~m}$ a.s.1.

\subsection{Seasonal biology}

Fig. 2 shows seasonal biology of $M$. albocilia in southwestern Slovakia. The insect overwintered as pupa, and the emergence of the first generation adults started in the beginning of May and continued until the end of May in an outdoor insectary. Fifty-two adults were recovered in the spring of

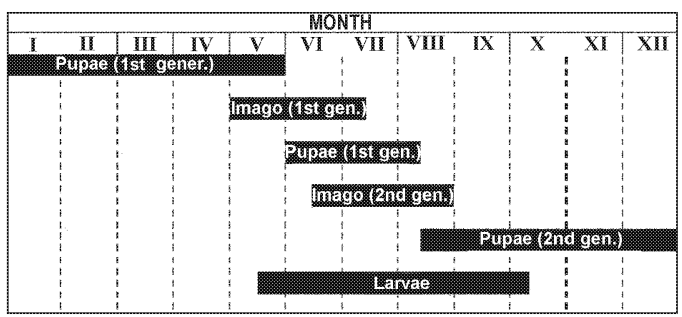

Fig. 2. Seasonal biology of $M$. albocilia Hendel in southwestern Slovakia (based on the data from localities Tehla, Malá $n$ / Hronom and Čajkov; Table 1).

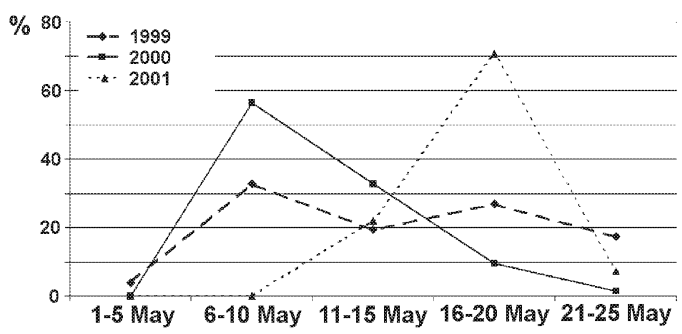

Fig. 3. M. albocilia adult emergence in outdoor insectary during the spring 1999-2001 (the ratio (\%) from the total adults emerged during spring each year). 
Table 2. Population dynamics of $M$. albocilia at three localities in Slovakia in 1999. Numbers of specimens are based on totals for 30 plants each date.

\begin{tabular}{|c|c|c|c|c|c|c|c|c|c|}
\hline \multirow[t]{2}{*}{ Date } & \multicolumn{3}{|l|}{ Tehla } & \multicolumn{3}{|c|}{ Malá n / Hronom } & \multicolumn{3}{|l|}{ Čajkov } \\
\hline & $L^{a}$ & $P^{b}$ & $\mathrm{PL}^{\mathrm{c}}$ & L & $P$ & PL & L & $\mathrm{P}$ & PL \\
\hline 1-10 June & $0.26 \pm 0.09$ & $0.19 \pm 0,08$ & 0 & - & - & - & - & - & - \\
\hline 11-20 June & $0.28 \pm 0.27$ & $0.29 \pm 0.32$ & 0 & - & - & - & - & - & - \\
\hline 21-30 June & - & - & - & - & - & - & - & - & - \\
\hline 1-10 July & $0.10 \pm 0.09$ & $0.97 \pm 0.11$ & 0 & - & - & - & - & - & - \\
\hline 11-20 July & $0.45 \pm 0,50$ & $0.69 \pm 0.45$ & $0.03 \pm 0.05$ & $0.20 \pm 0.24$ & 0 & 0 & $0.26 \pm 0.31$ & $0.24 \pm 0.11$ & 0 \\
\hline 21-31 July & $0.89 \pm 0.11$ & $0.61 \pm 0.51$ & $0.19 \pm 0.09$ & $0.54 \pm 0.09$ & $0.97 \pm 0.43$ & $0.08 \pm 0.09$ & $0.33 \pm 0.09$ & $0.61 \pm 0.41$ & $0.16 \pm 0.11$ \\
\hline 1-10 Aug. & $1.37 \pm 0.75$ & $1.00 \pm 0,46$ & $0.41 \pm 0.31$ & $1.30 \pm 0.44$ & $0.78 \pm 0.10$ & $0.55 \pm 0.44$ & $0.23 \pm 0.11$ & $0.63 \pm 0.17$ & 0 \\
\hline 11-20 Aug. & $1.76 \pm 0.73$ & $0.96 \pm 0.32$ & $0.51 \pm 0,21$ & $1.06 \pm 0.38$ & $0.74 \pm 0.42$ & $0.57 \pm 0.22$ & $0.47 \pm 0.30$ & $0.52 \pm 0.14$ & $0.21 \pm 0.27$ \\
\hline 21-31 Aug. & $2.92 \pm 0.24$ & $1.15 \pm 0.26$ & $0.64 \pm 0.56$ & $1.06 \pm 0.15$ & $0.84 \pm 0.15$ & $0.41 \pm 0.16$ & $0.22 \pm 0.01$ & $0.22 \pm 0.29$ & $0.18 \pm 0.06$ \\
\hline 1-10 Sept. & $2.35 \pm 0.78$ & $1.02 \pm 0.57$ & $1.58 \pm 0.66$ & $0.88 \pm 0.41$ & $0.72 \pm 0.38$ & $0.30 \pm 0.22$ & $0.39 \pm 0.22$ & $0.31 \pm 0.30$ & $0.22 \pm 0.19$ \\
\hline 11-20 Sept. & $1.04 \pm 0.11$ & $1.93 \pm 0.91$ & $2.10 \pm 0.30$ & $0.47 \pm 0.14$ & $0.46 \pm 0.34$ & $0.60 \pm 0.53$ & $0.45 \pm 0.28$ & $0.38 \pm 0.12$ & $0.18 \pm 0.07$ \\
\hline 21-30 Sept. & $1.73 \pm 0.24$ & $0.67 \pm 0.17$ & $1.64 \pm 0.72$ & - & - & - & - & - & - \\
\hline
\end{tabular}

a Mean of larvae per 10 evaluated stems \pm SEM

b Mean of pupae per 10 evaluated stems \pm SEM

c Mean of parasitized larvae per 10 evaluated stems \pm SEM

1999, 64 in 2000 and 39 in 2001 from the pupae collected in the fall season. Maximum adult emergence was from 6-10 May 1999 and 2000 $(52.0 \%$ and $89.1 \%$ ) but from 16-20 May 2001 (70.7\%) (Fig. 3). The first empty pupal cases within the field bindweed stems were found during the second half of June. Second-generation adults occurred during a relatively long period (June-August 1999). The first flies of the second generation emerged from the field collected pupae on 17 June 1999 in an outdoor insectary. The last adult of the second generation emerged on 28 August 1999 during the study. $7.3 \%$ of the second-generation adults were collected in June, $30.9 \%$ in July, but the majority $(61.8 \%)$ within August 1999.

Larvae were found from the middle of May until the end of growing season. The highest numbers were found during August and in the first half of September. Although the peaks were similar at all three localities evaluated, the numbers of larvae (but also pupae) per 10 stems were markedly lower at Malá n/Hronom and Čajkov (Tables 2-3). From June to the beginning of September, the number of larvae fluctuated from 0.10 \pm 0.09 to $2.92 \pm 0.24$ in 1999 and $0.10 \pm 0.17$ to $1.45 \pm 0.41$ (means and standard errors are given here and hereafter) per 10 stems in 2000 at the locality Tehla. At Malá n/Hronom, the maximum was $1.30 \pm 0.44$ larvae per 10 stems in 1999 , but only $0.94 \pm 0.35$ at Čajkov in 2000 . The occurrence of larvae was constant during the study. The number of larvae decreased sharply during September.

The first pupae were found at the beginning of June and the number reached a maximum from August through September. The number of pupae per 10 stems reached a maximum of $1.93 \pm 0.91$ from 11-20 Sept. 1999 and $0.72 \pm 0.20$ from $1-10$ Sept. 2000 at Tehla. Nevertheless, the maximum of pupae was recorded in July at Malá n/Hronom each year (Tables 2-3).

The number of pupae was markedly reduced as a result of high larval mortality due to parasitism. Although the first larval parasitoids were observed already during June, the larval parasitization was relatively low. The proportion of parasitized larvae was $22.6 \%$ at Tehla, $19.2 \%$ at Malá n/Hronom and $16.7 \%$ at Čajkov in June 2000. The number of parasitized larvae increased until the end of vegetation in September. During September 2000, the parasitized larvae constituted $60.4 \%, 57.5 \%$, and $41.2 \%$ of the all developmental specimens recorded in Tehla, Malá $\mathrm{n} /$ Hronom and Čajkov, respectively. All of the larval parasitoids were identified as Bracon picticornis Wesmael, 1838 (Hymenoptera: Braconidae). While the larval parasitization was sta- 
Table 3. Population dynamics of M. albocilia at three localities in Slovakia in 2000. Numbers of specimens are based on totals for 30 plants each date.

\begin{tabular}{|c|c|c|c|c|c|c|c|c|c|}
\hline \multirow[t]{2}{*}{ Date } & \multicolumn{3}{|l|}{ Tehla } & \multicolumn{3}{|c|}{ Malá n / Hronom } & \multicolumn{3}{|l|}{ Čajkov } \\
\hline & $\mathrm{L}^{\mathrm{a}}$ & $p^{b}$ & $\mathrm{PL}^{\mathrm{c}}$ & $L$ & $P$ & PL & $\mathrm{L}$ & $P$ & $\mathrm{PL}$ \\
\hline $1-10$ June & $0.10 \pm 0.17$ & $0.05 \pm 0.08$ & 0 & $0.37 \pm 0.18$ & $0.32 \pm 0.19$ & $0.04 \pm 0.07$ & - & - & - \\
\hline 11-20 June & $0.35 \pm 0.15$ & $0.24 \pm 0.14$ & $0.08 \pm 0.07$ & $0.48 \pm 0.34$ & $0.49 \pm 0.35$ & $0.08 \pm 0.07$ & $0.08 \pm 0.07$ & $0.16 \pm 0.18$ & 0 \\
\hline 21-30 June & $0.73 \pm 0.41$ & $0.30 \pm 0.11$ & $0.36 \pm 0.32$ & $0.72 \pm 0.11$ & $0.44 \pm 0.19$ & $0.48 \pm 0.12$ & $0.31 \pm 0.32$ & $0.13 \pm 0.12$ & $0.13 \pm 0.12$ \\
\hline $1-10$ July & $0.84 \pm 0.44$ & $0.41 \pm 0.18$ & $0.50 \pm 0.10$ & $0.36 \pm 0.10$ & $0.88 \pm 0.23$ & $0.71 \pm 0.40$ & - & - & - \\
\hline 11-20 July & $1.30 \pm 0.41$ & $0.48 \pm 0.19$ & $0.56 \pm 0.47$ & $0.54 \pm 0.35$ & $1.20 \pm 0.33$ & $0.45 \pm 0.04$ & $0.15 \pm 0.16$ & $0.44 \pm 0.16$ & $0.20 \pm 0.18$ \\
\hline 21-31 July & $1.25 \pm 0.50$ & $0.37 \pm 0.12$ & $0.93 \pm 0.19$ & $0.50 \pm 0.32$ & $1.08 \pm 0,28$ & $0.24 \pm 0.22$ & $0.46 \pm 0.05$ & $0.26 \pm 0.33$ & $0.23 \pm 0.09$ \\
\hline 1-10 Aug. & $1.44 \pm 0.29$ & $0.34 \pm 0.28$ & $0.88 \pm 0.34$ & $0.66 \pm 0.32$ & $0.72 \pm 0.46$ & $0.37 \pm 0.22$ & $0.94 \pm 0.35$ & $0.38 \pm 0.17$ & $0.54 \pm 0.37$ \\
\hline 11-20 Aug. & $1.45 \pm 0.41$ & $0.40 \pm 0.40$ & $1.32 \pm 0.33$ & $0.66 \pm 0.26$ & $0.63 \pm 0.20$ & $0.56 \pm 0.50$ & $0.74 \pm 0.39$ & $0.65 \pm 0.42$ & $0.40 \pm 0.29$ \\
\hline 21-31 Aug. & $1.19 \pm 0.51$ & $0.55 \pm 0.31$ & $1.16 \pm 0.47$ & $0.72 \pm 0.30$ & $0.53 \pm 0.12$ & $0.95 \pm 0.39$ & $0.36 \pm 0.27$ & $0.50 \pm 0.15$ & $0.55 \pm 0.26$ \\
\hline 1-10 Sept. & $1.06 \pm 0.49$ & $0.72 \pm 0.20$ & $1.01 \pm 0.20$ & - & - & - & - & - & - \\
\hline 11-20 Sept. & $1.00 \pm 0.37$ & $0.66 \pm 0.19$ & $1.41 \pm 0.51$ & $0.68 \pm 0.13$ & $0.62 \pm 0.19$ & $1.09 \pm 0.16$ & $0.45 \pm 0.39$ & $0.91 \pm 0.30$ & $0.50 \pm 0.44$ \\
\hline 21-30 Sept. & $0.52 \pm 0.33$ & $0.66 \pm 0.18$ & $1.29 \pm 0.36$ & $0.23 \pm 0.22$ & $0.39 \pm 0.19$ & $0.50 \pm 0.10$ & $0.34 \pm 0.14$ & $0.35 \pm 0.21$ & $0.51 \pm 0.29$ \\
\hline
\end{tabular}

a Mean of larvae per 10 evaluated stems \pm SEM

b Mean of pupae per 10 evaluated stems $\pm S E M$

c Mean of parasitized larvae per 10 evaluated stems \pm SEM

ble among populations at different localities annually, there were apparent differences in 1999 and 2000. The parasitization was higher during 2000 and reached $51.9 \%$ at Čajkov, $55.8 \%$ at Malá n/Hronom and $56.0 \%$ at Tehla. On the other hand, during 1999 it reached only $35.2 \%, 35.2 \%$ and $38.3 \%$ respectively. Besides parasitization, a generally high percentage of dead larvae within the stems was found, especially from the second

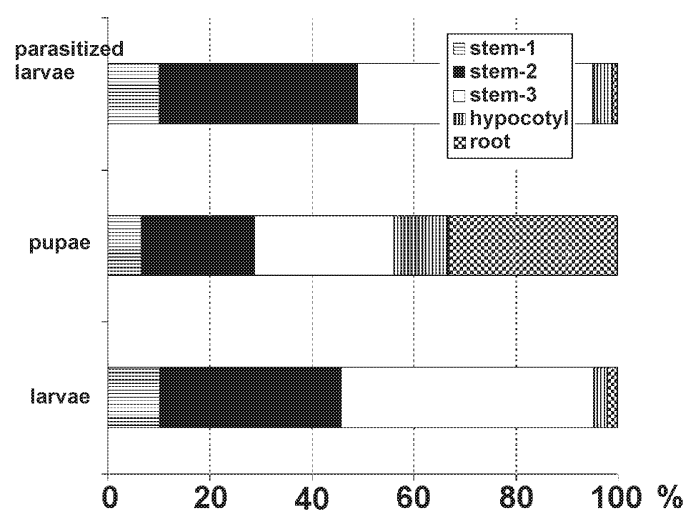

Fig. 4. Distribution of M. albocilia developmental specimens within the field bindweed stems (expressed in\%) at the Tehla, Malá n/Hronom and Čajkov localities in 1999 and in 2000, where stem-1 means upper third, stem-2 middle third and stem-3 lower third of stems. half of August to the end of the season. Dead larvae amounted sometimes up to $90 \%$ of fall larval populations.

The positions of larvae, pupae and parasitized larvae recorded inside the field bindweed stems are summarized in Fig. 4. The highest number of larvae was found in the middle and in the lower thirds of the stems, this proportion amounted to $35.7 \%$ and $49.7 \%$ respectively. The number of larvae in hypocotyles and roots was smaller $(2.6 \%$ and $2.1 \%)$. Although the pupae were distributed more uniformly within the stems, the majority of pupae were recorded in the lower third of stems and in the roots. It was clear, that larvae generally moved to the lower parts of the plant for pupation. The positions of parasitized larvae were similar to those of uninfested larvae (= healthy larvae) (Fig. 4).

\subsection{Infestation of host plant}

During the period of 1999-2000, a total of 2160 C. arvensis plants were sampled at the three weekly checked localities of Slovakia. From these, 1,492 plants $(69.0 \%)$ were infested by $M$. albocilia (having one or more specimens in the stems). Altogether $17.0 \%$ of the 18,063 evaluated stems were attacked. 


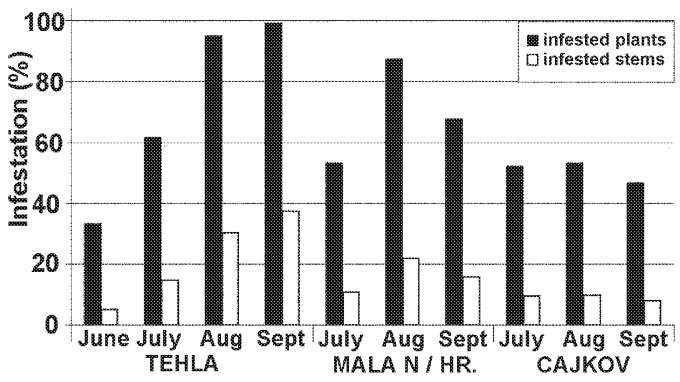

Fig. 5. Field bindweed infestation by Melanagromyza albocilia under the field conditions of three weekly sampled localities in Slovakia in 1999. The data are based on totals for 30 plants sampled each date.

M. albocilia generally infested field bindweed throughout the season (Figs. 5-6). The infestation was initially low, reaching only $33.3 \%$ of infested field bindweed plants in June 1999 and $37.3 \%$ in June 2000 at Tehla locality. Similarly, only $28.3 \%$ of infestation was recorded at Čajkov during June 2000. An exception was found at Malá $\mathrm{n} /$ Hronom with $56.7 \%$ of infested plants in June 2000. The infestation reached its peak from August through September. The percentage of infested plants was very high at Tehla. It reached $99.2 \%$ in 1999 and $96.0 \%$ in 2000 . During the same period, infestation rates reached a maximum of $87.5 \%$ at Malá $\mathrm{n} /$ Hronom and $71.7 \%$ at Čajkov (Figs. 5-6).

At all three localities, the number of field bindweed stems infested by $M$. albocilia increased generally from June to September. The percentage of infested stems was the highest at Tehla, where it rose from $5.1 \%$ in June to $37.2 \%$ in September 1999 and from $7.3 \%$ to $25.2 \%$ in 2000. The lowest infestation was recorded at Cajkov, reaching the maximum of $9.7 \%$ in September 1999 and 16.1\% in September 2000 (Figs. 5-6).

Populations of $M$. albocilia in the samples taken from the three regularly checked sites were highest in 1999, with mean densities of $3.21 \pm$ $2.13,2.21 \pm 1.56$, and $1.57 \pm 1.01$ larvae or pupae per infested plant at Tehla, Malá $\mathrm{n} /$ Hronom and Čajkov, respectively. Numbers declined in 2000 , with an average of only $2.23 \pm 1.55,1.75 \pm 0.92$, and $1.51 \pm 0.89$ specimens per plant. The highest population was found at Tehla. During 1999 and 2000 , there were about 3.7 times more specimens

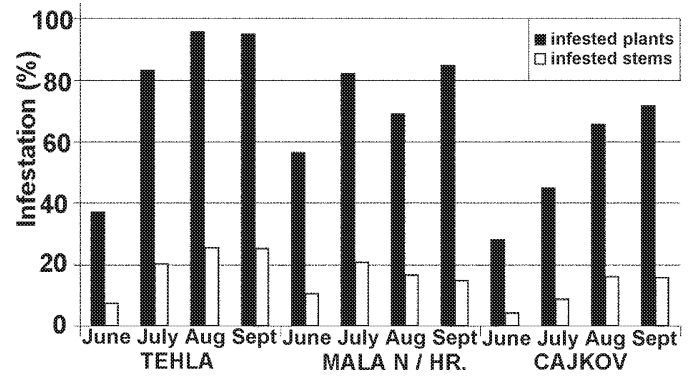

Fig. 6. Field bindweed infestation by Melanagromyza albocilia under the field conditions of three weekly sampled localities in Slovakia in 2000. The data are based on totals for 30 plants sampled each date.

at Tehla locality than it was at $\breve{C a j k o v}$ and two times more than at Malá $\mathrm{n} /$ Hronom. The results also revealed that the number of specimens in the stems infested by $M$. albocilia varied from $0.84 \pm$ 0.40 to $1.34 \pm 0.50$. The numbers were stable within each locality and year (Figs. 7-8).

\section{Discussion}

From our results it is clear that $M$. albocilia is widely distributed in the plains and foothills of Slovakia. It was present at all sites checked (Fig. 1) with mean infestation range from $1.51 \pm 0.89$ to $3.21 \pm 2.13$ specimens per plant (Figs. 7-8). Such a distribution had not been observed earlier, supposedly because of its hidden biology.

The stem borer was apparently more rare in hilly areas. Probably in such conditions only one generation of the insect develops even under lower press of parasites.

Although $M$. albocilia infested field bindweed throughout the season, the difference between early (June) and later attack (August-September) was evident. The clear maximum of infestations generally occurred in late summer and fall. The similar species, $M$. convolvuli, completed a generation within 26-39 days in Pakistan (Baloch 1977). Melanagromyza sojae (Zehntner, 1900) developed in about three weeks on soybeans in Indonesia (van der Goot 1930), and $M$. socolena developed similarly on tomatoes in Colombia (Zenner de Polania 1995). But, all these three species live in subtropical or tropical climate where development is influenced not only 


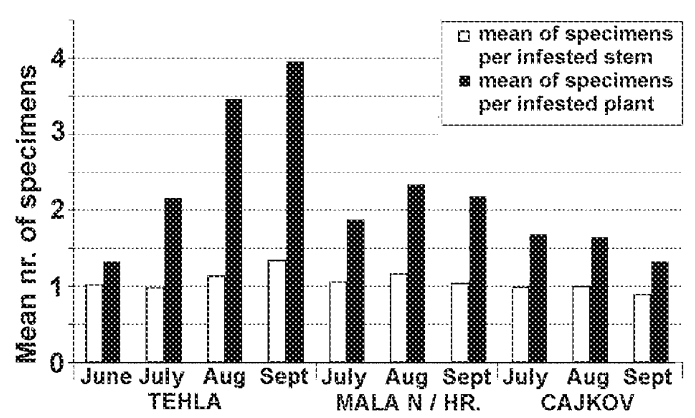

Fig. 7. Mean number of M. albocilia specimens (larvae, pupae, parasitized larvae) per infested stems and plants of field bindweed under the field conditions of three weekly sampled localities in Slovakia in 1999. Numbers of specimens are based on totals for 30 plants evaluated for each date.

by temperature but also other factors influencing diapause. In the case of $M$. albocilia we assume that it has two overlapping generations per year in Slovakia. Prolonged emergence of the second generation adults might indicate that partial third generation could occur. Larvae and pupae were found side by side throughout the season.

The later attack of the stem borer fly, considered as the second generation, caused the heaviest infestation of field bindweed plants (up to 100\%) and increased also the number of stems attacked (Figs. 5-6). Similarly, M. convolvuli infested up to $63 \%$ of field bindweed plants in Pakistan (Baloch 1977).

In contrast to $M$. sojae, which reached maximally 1.35 specimens per plant in Sumatra (van den Berg et al. 1995), the densities of $M$. albocilia were considerably higher in Slovakia. Peak densities generally occurred through August and September with $3.95 \pm 2.03,2.34 \pm 1.65$, and 1.68 \pm 1.13 live specimens per plant recorded at Tehla, Malá n/Hronom and Cajkov, respectively (Figs. 7-8). Van der Goot (1930) reported that several eggs were deposited per plant but only one or sometimes two larvae of $M$. sojae were found in the same feeding tumel, suggesting that intraspecific competition was important. Similarly, the number of specimens in the stems infested by M. albocilia varied from $0.84 \pm 0.40$ to $1.34 \pm$ 0.50 . Nevertheless, we sometimes found up to 5 specimens per stem what does not indicate strong intraspecific competition of the species.

Parasitism of $M$. albocilia larvae in Slovakian

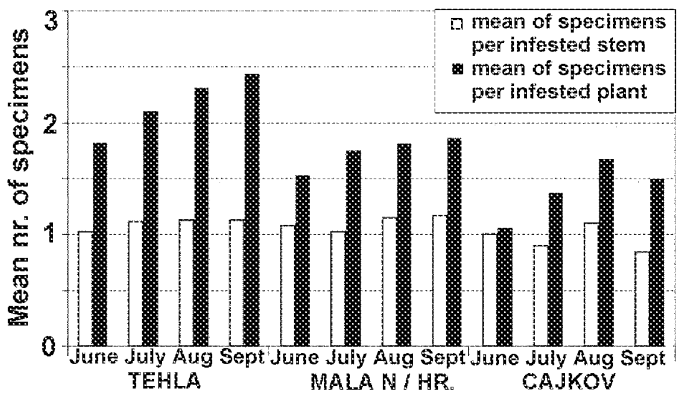

Fig. 8. Mean number of $M$ albocilia specimens (larvae, pupae, parasitized larvae) per infested stems and plants of field bindweed under the field conditions of three weekly sampled localities in Slovakia in 2000. Numbers of specimens are based on totals for 30 plants evaluated each date.

fields by $B$. picticornis was important in limiting of the species. B. picticornis showed the ability to forage effectively for larvae even in a relatively lower population level of $M$. albocilia (for example, Cajkov locality). It is a generalist larval ectoparasitoid. It has been reared for instance from Euphranta connexa (F.) (Diptera: Tephritidae) (Solbreck 2000), leafrollers in the family Tortricidae (Lepidoptera) (Diaconu \& Lozan 2000), and Pontania proxima (Lepeletier) (Hymenoptera: Tenthredinidae) (Al-Saffar \& Aldrich 1997). M. albocilia is a new host for B. picticornis.

In addition to parasitism, high larval mortality was observed through August and September. Similarly, Wang (1979) noted high larval mortality of $M$. sojae, the actual reason for this mortality remains to be investigated.

Feeding by M. albocilia larvae in stems apparently did not impede the supply of water and nutrients to the upper parts of the plant. During the larval period infested plants looked healthy from the outside. The stems started to become weak and dry after pupation, which takes place directly within the stems, probably because the larva gnaws an oval exit hole cutting off water and nutrients flow to the upper part.

Larvae of $M$ albocilia bore only in stem and roots of plant within the genus Convolvulus (Spencer 1973, Awadallah et al. 1976, Rosenthal \& Buckingham 1982). The species appears to be highly host specific. Spencer (1965) mentioned: "When a species from the family Agromyzidae is feeding within stems or seeds there is a high de- 
gree of probability that such species will be strictly monophagous". Before ovipositing, females puncture field bindweed leaves and feed on the ensuing exudates (Awadallah et al. 1976). Spencer (1973) suggested three reasons for such behavior: firstly, to confirm that the host is correct; second, to ingest proteins from the host which are necessary for maturation of the ovaries; and third, the actual feeding on the available carbohydrates. Baloch (1977) found that freshly emerged females of $M$. convolvuli that had not fed on leaf juices of field bindweed laid only infertile eggs when feeding on sweet potato (Ipomoea batatas Linnaeus). Based on our data (unpubl.), it is clear that $M$. albocilia does not attack I. batatas. We propose that $M$. albocilia may be a promising biological control agent of field bindweed not only in this respect. This species might also be a promising candidate for its primary damage: its stem-boring feeding after pupation results in weakness and dryness of stems, as shown by Tóth (2000). In addition, it probably causes secondary damage e.g. by "opening the door" to several pathogens, such as fungi and bacteria, which can in turn increase the total damage and even cause deaths of the target weed. Mines formed during larval feeding increase the risk of infection (Tóth et al. 2000). Based on all of the aforementioned, together with a high infestation of the host plant, we conclude that $M$. albocilia can be an important biological control agent of $C$. arvensis, especially if it is imported to places where $C$. arvensis is an invasive plant without associated insect fauna (e.g. in North America). There is also the presumption that $M$. albocilia will not experience high parasitism rates in such areas.

Acknowledgements. We would like to thank Dr. Josef Lukáš (Department of Ecology, Comenius University, Bratislava, Slovakia) for parasitoid identification and Dr. Lloyd Knutson (Cornell University, USDA, retired) for useful comments on the manuscript. Part of this work was supported by the Grant Agency VEGA, project No $1 / 2424 / 05$.

\section{References}

Al Saffar, Z. Y. \& Aldrich, J. C. 1997: Factors influencing the survival of Pontania proxima that attack crack willow Salix fragilis. — Biology and Environment: Pro- ceedings of the Royal Irish Academy 97, Royal Irish Academy, 219-223.

Awadallah, K. T., Tawfik, M. F. S. \& Shalaby, F. F. 1976: Insect fauna of bind-weed, Convolvulus arvensis L., in Giza, Egypt. - Bull. Soc. ent. Egypte 60: 15-24.

van den Berg, H., Ankasah, D., Hassan K., Muhammad, A., Widayanto, H. A., Wirasto, H. B. \& Yully, I. 1995: Soybean stem fly, Melanagromyza sojae (Diptera: Agromyzidae), on Sumatra: Seasonal incidence and the role of parasitism. - International Journal of Pest Management 41: 127-133.

Baloch, G. M. 1974: Phytophagous organisms associated with bindweed, Convolvulus spp., in Pakistan. Techn. Bull. Commonw. Inst. Biol. Contr. 17:29-36.

Baloch, G. M. 1977: Insects as biological control agents of field bindweed, Convolvulvs arvensis. - PANS 23: $58-64$.

Défago, G., Ammon, H. U., Cagáň, L., Draeger, B., Graeves, M. P., Guntli, D., Hoeke, D., Klimes, L., Lawrie, J., Moënne-Loccoz, Y., Nicolet, B., Pfirter, H. A., Tabacchi, R. \& Tóth, P. 2001: Towards the biocontrol of bindweeds with a mycoherbicide. - Biocontrol 46: 157-173.

Diaconu, A. \& Lozan, A. 2000: Ectoparasitoid braconids (Hym.: Braconidae) of certain species of leafrollers (Lep.: Tortricidae) of fruit trees. - Mitt. Schweiz. Ent. Gesell. 73: 5-11.

van der Goot, P. 1930: De Agromyza-vliegjes der inlandse katjang-gewassen op Java. Mededeelingen van het Instituut voor Plantenziekten. - Asian Vegetable Research and Development Center, Shanhua, Taiwan, China. 78 pp.

Hendel, F. 1938: Agromyzidae. - In: Lindner, E. (ed.), Die Fliegen der Palaearktischen Region: 1-570. Stuttgart, Germany.

Mohyuddin, A. I. 1969: Insect from Calystegia spp. and Convolvulus spp. 1-570. - Techn. Bull. Commonw. Inst. Biol. Contr. 11: 93-104.

Rosenthal, S. S. \& Buckingham, R. G. 1982: Natural enemies of Convolvulus arvensis in western Mediterranean Europe. - Hilgardia 5: 1-19.

Solbreck, C. 2000: Ecology and biology of Euphranta connexa (Fabr.) (Diptera: Tephritidae) - a seed predator on Vincetoxicum hirundinaria Med. (Asclepiadaceae). - Ent. Tidskr. 121: 23-30.

Soós, A. \& Papp, L. 1984: Catalogue of Palaearctic Diptera. Micropezidae-Agromyzidae. Vol. 9. - Elsevier, Budapest.

Spasic, R. \& Smiljanic, D. 1999: Stem-mining flies (Diptera, Agromyzidae) as potential weed biocontrol agents. - In: Peric, I. \& Ivanovic, M. (eds.), Proceedings of International Symposium on Integrated Protection of Field Crops, 25 September 1998, Vrnjačka Banja, Yugoslavia: 129-135. Plant Protection Society of Serbia, Belgrade.

Spencer, K. A. 1965: The species-host relationship in the Agromyzidae (Diptera) as an aid to taxonomy. - Proceedings of International Congress of Entomology, 13 July 1965: 101-102.

Spencer, K. A. 1966: A revision of European species of the 
genera Melanagromyza Hendel and Hexomyza Enderlein, with a supplement on the genus Ophiomyia Braschnikov. - Beitr. Ent. 16: 3-60.

Spencer, K. A. 1971: A new Agromyzid (Diptera) from Pakistan feeding as a stem-borer in Convolvulus arvensis. — Bull. Ent. Res. 61: 369-371.

Spencer, K. A. 1973: Agromyzidae (Diptera) of Economic Importance. - Dr. W. Junk B. V., The Hague, Netherlands.

Spencer, K. A. 1974: Some Agromyzidae (Diptera) from Israel. - Israel J. Ent. 9: 141-157.

Spencer, K. A. 1976: The Agromyzidae (Diptera) of Fennoscandia and Denmark. Fauna Entomologica Scandinavica, Vol 5. - Scandinavian Science Press Ltd. Klampenborg, Denmark.

Tóth, P. 2000: Insects - A Fresh Perspective in the Biological Control of Field Bindweed (Convolvulus arvensis L.). - PhD thesis, Slovak Agricultural University, Nitra, Slovakia. 229 pp.

Tóth, P. \& Cagáň, L. 2005: Organisms associated with the family Convolvulaceae and their potential for biological control of Convolvulus arvensis. - Biocontrol News and Information 26: $17 \mathrm{~N}-40 \mathrm{~N}$.

Tóth, P., Cristofaro, M. \& Cagáň, Ĺ. 2000: Field observations and biological notes of the entomofauna associated with Convolvulus arvensis L. in Slovakia. - In: Spencer N. R. (ed.), Proceedings of the X International Symposium on Biological Control of Weeds: 145. United States Department of Agriculture, Agricultural Research Service, Sidney, and Montana State University, Bozeman, MT, USA. 1030 pp.

Tóth, P., Tóthová, M. \& Cagáň, L. 2003: Emmelina monodactyla (Linnaeus, 1758) (Lepidoptera: Pterophoridae), its parasitization and potential as a biologi- cal control agent of Field or Lesser Bindweed (Convolvulus arvensis L.). - Entomologist's Gazette 54: 233-241.

Tóth, P., Vráblová, M. \& Cagáň, L. 1997: Importance of noctuid species for biological control of Field Bindweed (Convolvulus arvensis L.) and Hedge Bindweed (Calystegia sepium L.). - Proceedings of XIV Slovak and Czech Plant Protection Conference, Nitra: 301302.

Tóth, P., Vráblová, M. \& Cagáň, L. 1998: First record of Melanagromyza albocilia (Agromyzidae, Diptera) from Slovakia. - Biologia Bratislava 53: 604.

Tóth, P., Vráblová, M. \& Cagán̆, L. 2001: Bionomics of Spermophagous sericeus (Geoffroy) (Coleoptera: Bruchidae) - a potential biological control agent of Convolvulus arvensis L. - Acta Fytotechnica et Zootechnica 4 (Special Number): 308-309.

Vála, M. \& Černý, M. 1997: Agromyzidae. - In: Chvála, M. (ed.), Checklist of Diptera (Insecta) of the Czech and Slovak Republics: 75-78. Karolinum, Charles University Press, Prague, Czech Republic. 130 pp.

Zat'ko, M. 2002: Primary landscape structure. - In: Landscape Atlas of Slovak Republic, 1 st ed., Ministry of Environment of the Slovak Republic, Banská Bystrica, Slovak Environmental Agency, Bratislava. 344 pp.

Zenner de Polania, I. 1995: Aspects of the biology and economics of Melanagromyza socolena (Diptera: Agromyzidae), a new pest of greenhouse tomato. Revta Col. Ent. 21: 9-14.

Wang, C. L. 1979: Occurrence and life history of Melanagromyza sojae on soybean. - J. Agric. Res. China 28: 217-223. 